Resenha / Review

\title{
O império da dor
}

The empire of pain

El imperio del dolor

Daniel Afonso da Silva ${ }^{1}$

\section{Resenha de:}

\section{BADIE, Bertrand. Un monde de souffrances. Ambivalence de la mondialisation. Paris: Salvator, 2015.}

Bertrand Badie domina a arte de surpreender, provocar e cativar. Autor e professor consagrado em todo o mundo como refinado analista político e observador do meio internacional, ele vem há mais de quarenta anos ampliando nossos instrumentos de apreensão política das realidades internacionais. Sociologie de l'état (1979), La fin de territoire (1995), Un monde sans souveraineté (1999), L'impuissance de la puissance (2004), Le diplomate et l'intrus (2008), La diplomatie de connivence (2011), Quand l'Histoire commence (2013), Le temps des humiliés (2014) são apenas algumas de suas provocações-texto.

Un monde de souffrances (Badie, 2015) consiste na mais recente.

Nele Badie afirma e demonstra que o mundo hodierno vive sob o império da dor e do sofrimento. Pessoas de carne e osso, em sua individualidade e singularidade, alegria e frustração, adentraram essa cena social internacional para não mais sair. Viraram protagonistas incontestáveis de todos os processos políticos nacionais e transnacionais.

$\mathrm{O}$ aprofundamento da mundialização nos últimos trinta, quarenta anos tornou anacrônicas e improcedentes todas as visões de mundo que desprezam esse fato. Cientistas políticos e teóricos das relações internacionais parecem os únicos a grandemente desprezar essa verdade. E por isso suas abordagens

\footnotetext{
${ }^{1}$ Núcleo de Pesquisas em Relações Internacionais da Universidade de São Paulo (Nupri-USP), São Paulo, SP, Brasil.

autor.dados_biográficos
} 
são mais e mais frágeis e inconsequentes e descompromissadas com tudo que escapa - leva a intuir Badie - ao tacanho e perverso carreirismo universitário dos dias que correm.

Un monde de souffrances representa, antes e acima de tudo, uma denúncia a essa irresponsabilidade política da miopia e má-fé dos acadêmicos -especialmente das relações internacionais- que assola o mundo inteiro.

Recolho de trinta e dois artigos de Badie publicados ao longo dos últimos dez anos no periódico La Croix, seu novo livro explicita claramente a tensão entre o mundo dos gabinetes e o mundo real das relações e relações internacionais.

Depositária da ciência política, na visão de Badie, as relações internacionais acabaram por incorporar as concepções daquela em sua abordagem do meio internacional. Especialmente a sua obsessão pela esfera do poder; e, em decorrência, pelo mundo das potências como genuínas fabricantes da guerra e da paz.

Mas os conflitos dos dias que correm, lembra o próprio Badie, independem de potências, concernem mais civis que militares, escapam aos domínios territoriais, constrange toda a eficácia dos princípios dos tempos de Hobbes, Clausewitz, Karl Marx e mesmo Hans J. Morgenthau.

Catástrofes naturais, modificações climáticas, epidemias, fome crônica, migração clandestina, ditaduras, racismo, desconsideração, humilhação. Nada disso escapa ao mundo mundializado que toca ao século 21 e aos seus tomadores de decisão e tudo isso acaba não cabendo das impressões teóricas clássicas ou neoclássicas dos internacionalistas contemporâneos.

As relações internacionais se consolidaram no imediatamente após 1945. Automaticamente elas se tornaram "uma ciência americana". Os Estados Unidos eram o único país com recursos humanos e materiais para essa empreitada. Seu escopo sugeria que a nação norte-americana tinha vencido sozinha a luta contra o nazismo. Esse raciocínio a conduziu a fundamentar a luta ideológica contra o totalitarismo soviético a partir de 1947.

Findo o conflito em 1989-1991, os Estados Unidos acreditaram novamente ter vencido a guerra. E assim impuseram sua lógica liberal especialmente pelo dito consenso de Washington. Mas a mundialização não tardou a estraçalhar essas pretensões de proeminência teórica (das relações internacionais) e política (dos Estados Unidos).

O 11 de setembro de 2001 foi a revanche de todos aqueles retirados da História ao longo da dita guerra fria. As primaveras árabes de 2010-2011 foram o momento dessa gente, com todas as suas frustrações, entrar efetivamente na História. Isso mostra que neste século 21 a sensibilidade para a questão social 
das relações internacionais virou agenda das relações internacionais. E essa sensibilidade vem conduzindo uma releitura do meio internacional com novos enfoques e novas periodizações.

Para Badie, a periodização segue balizada pela construção do mundo após 1945. Mas seu enfoque recai no impacto social da descolonização, da mundialização e do desaparecimento do mundo soviético.

No interior do processo massivo de descolonização foi criado o Programa das Nações Unidas para o Desenvolvimento (Pnud) em 1965. O Pnud foi o primeiro organismo internacional fundamentado em considerações sociais globais. Essa perspectiva que, desde o início, indicava modificações profundas na percepção do meio internacional, ganhou força em 1990 com a formulação do Índice de Desenvolvimento Humano (IDH). O objetivo do IDH não é outro que mapear a globalidade da condição social mundial a partir dos critérios renda per capita, escolarização e longevidade. Quatro anos depois, em 1994, o mesmo Pnud apresentaria sua proposição referente a segurança humana que concerne a atenção à segurança alimentar, sanitária, ambiental e política.

A exacerbação da mundialização especialmente após o fim da tensão Leste-Oeste pôs em evidência essas perspectivas e impôs a mobilização de outras agências das Nações Unidas como a Organização Mundial da Saúde (OMS) e a Organização das Nações Unidas para Alimentação e Agricultura (FAO) no mesmo objetivo de fazer a radiografia do sofrimento dos povos.

Quando fundada em 1948, a OMS tinha por meta simplesmente erradicar a varíola. Sua afirmação foi relativamente tardia e seus relatórios geralmente desprezados. Em 2008, seus representantes tiveram a perspicácia de demonstrar e a coragem de afirmar que, contrário a todas as aparências, uma em cada três mortes no mundo é causada mais por falta de dinheiro que por falta de remédio ou auxílio médico.

A FAO tivera sempre um orçamento diminuto e continua marginalizada no bojo das instituições onusianas. Seu pecado original de fundação, em 1945, foi ignorar desnutrição, que hoje aparece como uma constatação.

A atuação dessas agências - Pnud, OMS, FAO - permite uma ampla, senão completa, percepção social dos problemas mundiais que necessita ser levada em conta nas análises internacionais.

Desde 1980, a demografia mundial evoluiu de 4,5 para 7 bilhões de pessoas. Todos os índices em todos os países melhoraram. Entretanto, nos países pobres e ao sul, os números por vez enganam. Em 1981, 1,9 bilhão de pessoas vivia com US\$ 1,25 ao dia. Em 2015 esse percentual foi para 1 bilhão. Mas ao se alçar a barra aos US\$ 2,00, o número de pessoas pobres 
e fragilizadas sobe para 2,1 bilhões. Ou seja, aproximados 30\% da população mundial. Como desprezá-los, questiona Badie?

O mundo deixou claramente de ser o dos "gladiadores" dos tempos de Hobbes. A interconexão profunda dos tempos presentes sugere que todos dependem de todos. Uma agenda para a paz de Boutros Boutros-Ghali, secretário-geral das Nações Unidas em 1992, foi o primeiro documento a indicar essa interdependência ao diagnosticar que as guerras, após a tensão ideológica dos anos precedentes, resultariam de crises econômicas e sociais - $\mathrm{o}$ que se constatou em Ruanda e nos Balcãs, nas quais os Estados Unidos foram absolutamente reticentes simplesmente por desprezar essa aferição.

As conferências mundiais - Rio 92 sobre o clima, Cairo 94 sobre população, Copenhague 95 sobre desenvolvimento social, Pequim 95 sobre a condição feminina, Istambul 1996 sobre o habitat, Durban 2001 sobre o racismo - também serviram de instrumentos para redefinição das sensibilidades internacionais desse novo mundo. Mas o esforço maior nesse sentido viria com Kofi Annam e seus Objetivos do milênio em 2000.

A evidência de todos esses processos demonstra o já amplo mapeamento do grau de sofrimento crescente das populações em escala mundial. Un monde de souffrances de Bertrand Badie corresponde a uma tentativa de teorizá-lo e lançá-lo ao centro da reflexão internacional. A discussão segue aberta.

\section{Referência}

BADIE, Bertrand. Un monde de souffrances. Ambivalence de la mondialisation. Paris: Salvator, 2015.

Recebido em: 16 jan. 2018

Aprovado em: 28 fev. 2018

Autor correspondente

Daniel Afonso da Silva

Rua Vergueiro, 7071/136

04272-300 São Paulo, SP, Brasil

DANIEL AFONSO DA SILVA <daniel.afonso66@hotmail.com>

Doutor em História Social pela Universidade de São Paulo (USP, São Paulo, SP, Brasil), com estágio pós-doutoral no Centre des Recherches Internationales da Sciences Po em Paris, França. Atualmente é pesquisador no Núcleo de Pesquisas em Relações Internacionais da Universidade de São Paulo (Nupri-USP) em São Paulo, SP, Brasil. ORCID: https://orcid.org/0000-0002-9785-5894 